\title{
Bases for the construction of a QoS model for a video-calls service in a virtualized IMS network
}

María Camila Lara Paz / mclara@unicauca.edu.co

Heyman Andres Coral Sarria / hcorals@unicauca.edu.co

Eduardo Rojas Pineda / erojas@unicauca.edu.co / ORCID: 0000-0002-2113-0395

Grupo de Investigación en Ingeniería Telemática, Universidad del Cauca, Popayán-Colombia.

ABSTRACT Package-based services are affected by different network parameters and conditions that can deteriorate the quality of the transmitted services, especially those that are provided in real time. In this paper, result of an undergraduate research project, the bases for the construction of a QoS model are defined for a video call on an IMS network, specifying the most adequate parameters to estimate its QoS, the infrastructure used, and the tests developed. The results indicate the possibility of improving the QoS by applying the horizontal scaling technique over the IMS Core of the network since, in the vertical scalability, no major improvements were observed when increasing the physical resources of the virtual machines where the Core IMS was installed. Also, the bandwidth that complies the conditions of the quality parameters such as packet loss, delay, and jitter, to provide a good quality video call service is $640 \mathrm{kbps}$.

KEYWORDS Bandwidth; IMS; NGN; packet loss; QoS; SIP; video call.

Bases para la construcción de un modelo de calidad del servicio de videollamada en una red IMS virtualizada

RESUMEN Los servicios basados en paquetes se ven afectados por diferentes parámetros y condiciones de red que pueden deteriorar la calidad de los servicios transmitidos, principalmente los que se prestan en tiempo real. En este artículo, resultado de un proyecto de investigación de pregrado, se definen las bases para la construcción de un modelo de calidad del servicio [Quality of Service, QoS] para una videollamada sobre una red IMS, especificando los parámetros más adecuados que permiten estimar la QoS, la infraestructura utilizada y el plan de pruebas desarrollado. Los resultados obtenidos indican la posibilidad de mejorar la QoS aplicando la técnica de escalamiento horizontal sobre el núcleo IMS de la red, ya que en la escalabilidad vertical no se observaron mejoras al aumentar los recursos físicos de las máquinas virtuales donde se instaló el Core IMS. Además, el ancho de banda que cumple con las condiciones de los parámetros de calidad, tales como pérdida de paquetes, retardo y jitter, para brindar una buena calidad de servicio de videollamada, es de $640 \mathrm{Kbps}$.

PALABRAS CLAVE Ancho de banda; IMS; pérdida de paquetes; QoS; NGN; SIP; videollamada.
Bases para a construção de um modelo de qualidade do serviço de vídeo chamada em uma rede IMS virtualizada

RESUMO Os serviços baseados em pacotes são afetados por diferentes parâmetros e condições de rede que podem deteriorar a qualidade dos serviços transmitidos, especialmente aqueles que são fornecidos em tempo real. Neste artigo, resultado de um projeto de pesquisa de graduação, são definidas as bases para a construção de um modelo de Qualidade de Serviço (Quality of Service, QoS) para uma vídeo chamada de uma rede IMS, especificando os parâmetros mais adequados para estimar a QoS, a infraestrutura utilizada e o plano de testes desenvolvido. Os resultados obtidos indicam a possibilidade de melhorar a QoS aplicando a técnica de escalamento horizontal no núcleo IMS da rede, uma vez que na escalabilidade vertical não foram observadas melhorias ao aumentar os recursos físicos das máquinas virtuais onde o Core IMS foi instalado. Além disso, a largura de banda que atende às condições dos parâmetros de qualidade, como perda de pacotes, atraso e jitter, para fornecer uma boa qualidade do serviço de vídeo chamada é de 640 Kbps.

PALAVRAS-CHAVE Largura de banda; IMS; perda de pacotes; QoS; NGN; SIP; vídeo chamada. 


\section{Introduction}

The demand of the telecommunication services grows constantly and it requires that the networks supporting them are convergent and manageable (Nemati, Singhvi, Kara, \& El Barachi, 2014). The predominant trend is to implement a next generation network [NGN] in a virtualized environment based on IMS, capable to integrate itself with the current networks and that eases the evolution and adaptation of the services to attend the users' requirements (CRT, 2007).

Most of the telecommunication systems are migrating towards the so-called virtualized networks to take advantage of the benefits related to performance, portability, flexibility, and mainly cost reduction; further, the ease in the convergence with different telecommunication services such as multimedia and VoIP sessions is another benefit of the convergence. These virtualized networks should guarantee adequate quality of service [QoS] levels for the different types of services being transported within the network (Blandón et al, 2010).

The service assessed in this work is the video-call one, since it entails a typical telecommunications service (voice transmission) with a web multimedia service (video). Our purpose was to analyze and determine the QoS in the virtualized network of the TELCO2.0 platform of the Universidad del Canca. The quality of a video-call is sensible to the packet loss and the delays in transmission due to the real-time interaction between the users; consequently, it is necessary to follow an adequate methodology that permits the measurement of the implemented QoS in a virtualized network environment. This, in search of the determination on how the features of the service are affected. From there, the establishment of the service parameters to be controlled to satisfy the users requirements is the step to follow. Furthermore, it is important to analyze the features and components of the virtual network by using the advantages this latter offers to increase scalability and performance in the studied service.

A first approach to the topic indicates that there is not a well-established model to measure the quality of service in a video-call service over a virtualized network due to different factors such as the lack of standardization, the introduction of new technologies, and the lack of studies of this service in the IMS architecture. For this reason, one of the objectives of the work described in this document is to analyze the parameters that allow to measure the quality of that service in an IMS virtualized network, plus to examine the possible study cases in the network.

\section{Introducción}

La demanda de los servicios de telecomunicaciones crece de manera acelerada y requiere que las redes que los proporcionan sean convergentes y gestionables (Nemati, Singhvi, Kara, \& El Barachi, 2014). La tendencia predominante es implementar una infraestructura de Red de Próxima Generación [Next Generation Network, NGN] sobre un ambiente virtualizado, basado en IMS, que se integre con las redes ya existentes y que facilite la evolución y adaptación de los servicios para atender los diversos requerimientos de los usuarios (CRT, 2007). La mayoría de los sistemas de telecomunicaciones están migrando hacia redes virtualizadas con el fin de aprovechar todas las ventajas que ofrecen en rendimiento, portabilidad, flexibilidad y, principalmente, en la reducción de costos, además de facilitar la convergencia con diferentes servicios de telecomunicaciones, tales como sesiones multimedia y VoIP. Estas redes virtualizadas deben garantizar niveles de calidad de servicio [Quality of Service, QoS] adecuados para los diferentes tipos de servicios que transporta (Blandón et al, 2010).

El servicio que será propósito de investigación es el de videollamada, ya que integra un servicio de telecomunicaciones típico (transmisión de voz) con un servicio multimedia web (video), buscando analizar y determinar la QoS sobre la red virtualizada de la plataforma TELCO 2.0 de la Universidad del Cauca. La calidad de una videollamada es más sensible a la pérdida de paquetes y retrasos en la transmisión, debido a la interacción en tiempo real entre los usuarios. Por lo tanto, es necesario contar con una metodología adecuada que permita medir la QoS implementado sobre un ambiente de red virtualizado, para intentar determinar de qué manera se ven afectadas las características del servicio y, a partir de allí, establecer que parámetros del servicio deben ser controlados para satisfacer las necesidades de los usuarios. Además, es importante analizar las características y componentes de la red virtual, haciendo uso de las ventajas que esta ofrece para ganar escalabilidad, rendimiento y desempeño sobre el servicio estudiado.

Un primer acercamiento al tema indica que no se cuenta con un modelo bien establecido para medir la calidad de un servicio de videollamada sobre una red virtualizada, debido a diferentes factores como la falta de estandarización, la introducción de nuevas tecnologías y la falta de estudios de este servicio sobre la arquitectura de IMS, por lo cual uno de los objetivos de este trabajo fue analizar los parámetros que permitan medir la calidad de dicho servicio sobre una red IMS virtualizada y examinar los posibles casos de estudio sobre la red.

Este artículo se encuentra organizado de la siguiente manera: en la sección 2 se estructura el modelo de QoS, identificando los parámetros de calidad, la infraestructura utilizada y la caracterización de la red; en la sección 3 se describen el plan de pruebas y los resultados de su aplicación; y en la sección 4 se presentan las conclusiones. 


\section{Modelo de calidad de servicio}

Los servicios basados en paquetes se ven afectados por diferentes parámetros y condiciones de red que pueden deteriorar la calidad de los servicios que se transmiten, principalmente los que se prestan en tiempo real como juegos en línea, voz sobre IP [VoIP], video streaming, entre otros. Para mantener o mejorar la QoS, la red debe ofrecer condiciones favorables que garanticen una calidad de experiencia óptima a los usuarios finales. Es por ello que en el modelo se describen los parámetros de calidad más relevantes y la infraestructura de la red, y se realiza una caracterización de la misma para verificar la eficiencia y el rendimiento que esta tiene al implementar un servicio.

\section{A. Parámetros de calidad}

Se realizó una revisión bibliográfica sobre las variables que afectan la QoS en redes IMS, redes convergentes y redes virtualizadas, y se recopilaron los principales parámetros relacionados con el servicio de videollamada que pueden ser monitoreados en este tipo de redes. Los parámetros se clasificaron según la dependencia que existe entre ellos, obteniendo cuatro categorías, como se explicita en la TABLA 1.

Para constituir el modelo a través del cual determinar la QoS, se procedió a seleccionar los parámetros más significativos en cada una de las categorías identificadas. El criterio general para la selección fue que el parámetro abarcara todas o la gran mayoría de las características de las demás variables clasificadas dentro de dicha categoría. De esta manera, se busca que al obtener los resultados del monitoreo, éstas puedan de alguna forma representar la totalidad de la clasificación, simplificando el modelo y reduciendo el esfuerzo para determinar la QoS.

\section{Características físicas de la red}

En esta categoría se encuentran los parámetros que están relacionados con las características de la red para la transmisión y procesamiento de los paquetes, como el tipo de conexión, la congestión y los equipos utilizados. El parámetro seleccionado en esta categoría es el ancho de banda (Kurose \& Ross, 2013), ya que abarca las variables mencionadas y es uno de los parámetros más importantes en la red para ofrecer buena calidad de servicio. Entre más información se pueda trasportar en un intervalo de tiempo, los servicios y las aplicaciones funcionaran mejor, según sea la capacidad que el servicio requiera. El ancho de banda está directamente relacionado con el tipo de códec que se esté usando, si no se cuenta con un nivel adecuado de ancho de banda, el códec puede presentar saturación en el canal por insuficiencia en la capacidad, afectando la calidad de servicio.

\section{Retardo}

Estos parámetros dan cuenta de los tiempos de retardo que sufren los paquetes entre emisor y receptor en la red, es decir, los retardos presentes al establecer el servicio,
This article is organized as follow: section 2 presents the QoS model by identifying the quality parameters, the employed infrastructure, and the network characterization. Section 3 describes the test plan and the results of the application, whilst section 4 presents the conclusions.

\section{Quality of service model}

The packed-based services are affected by several parameters and network conditions that can deteriorate the quality of the transmitted services, mainly the ones distributed in real-time such as online games, voice over IP [VoIP], video streaming services, etc. With the aim of maintaining or improving the QoS, the network must offer favorable conditions that guarantee an optimal quality of experience to the end users.

\section{A. Quality parameters}

We performed a bibliographic revision related to the variables that might affect the QoS in IMS, convergent, and virtualized networks; we also gathered the main parameters related with the video-call service capable to be monitored in these networks. The parameters were classified as per its existing dependence amongst them, obtaining four categories, as TABLE 1 presents.

With the purpose of categorizing the model to determine the QoS, we selected the most significant parameters on each one of the identified categories. The general criterion for the selection was the encompassing of all (or at least, the majority) of the features from the other variables classified in such category. Consequently, we pursue that when obtaining the monitoring results, the variables can represent - somehow - the totality of the classification, simplifying the model and diminishing the effort to determine the QoS.

\section{Physical features of the network}

In this category, the parameters related with the network features for the packets transmission and processing are relevant. Some examples of this are the connection type, the congestion, and the employed equipment. The selected parameter in this category is the bandwidth (Kurose \& Ross, 2013), since it entails the mentioned variables and it is one of the most important parameters for the network to offer an acceptable QoS. The more information to be transported in a time interval, the better the services and applications will work depending on the capacity the service requires. The bandwidth is directly related with the employed codec; if the bandwidth is not adequate, the codec can entail a saturation situation in the channel due to inefficiency in the capacity, affecting the quality of service. 
Table 1. Classification of the quality parameters (Lara Paz \& Coral Sarria, 2017) / Clasificación de los parámetros de Calidad (Lara-Paz \& Coral-Sarria, 2017)

Category / Categoria
Physical features
of the network /
Caracteristicas fisicas
de la red

Delay / Retardo

Delay variation / Variación del retardo

Information loss /

Pérdida de información

Parameters / Parámetros

Bandwidth / Ancho de banda

Video bit speed / Velocidad de bits de video

Frames rate / Tasa de fotogramas paquetes IP [IPTD] duplicados [IPDR] replicados [RIPR] reordenados [IPRR]

Delay variation or jitter / Variabilidad del retardo o jitter [IPDV] a corto plazo

\section{Packet loss / Pérdida de paquetes}

End-to-end delay (latency) / Retardo "extremo a extremo" o latencia

Round-trip time [RTT] / Tiempo de retardo Round-Trip [RTT]

IP packet transfer delay [IPTD] / Retardo de transferencia de

IP packet duplicate relation [IPDR] / Relación de paquetes IP

Replicate IP packet relation [RIPR] / Relación de paquetes IP

IP packet reordered relation [IPRR] / Relación de paquetes IP

IP delay variation [IPDV] / Variación del retardo de paquetes IP

Quantification of the fluctuation/variation of the IP delay in the short term / Cuantificación de fuctuación / variación del retardo IP

Video frames loss / Pérdida de fotogramas de video

Burst density / Densidad de ráfaga

IP packet error relation [IPER] / Relación de error de paquetes IP [IPER]

IP packet loss relation [IPLR] / Relación de pérdida de paquetes IP [IPLR]

Spurious IP packet rate [SPR] / Tasa de paquetes IP espurios [SPR]

IP packet severe loss block relation [IPSLBR] / Relación de bloques de pérdida severa de paquetes IP [IPSLBR]

Consecutive packets loss event / Evento de pérdida de paquetes consecutivos

Degraded second / Segundo degradado

Discard window / Ventana de descarte desde el momento en que un usuario comienza la comunicación, pasando por todos los protocolos de señalización, memorias intermedias, procesos de empaquetamiento, codificación y envío de los paquetes, hasta la llegada de la información al receptor, la interpretación de la información, etc. En ésta categoría, el parámetro seleccionado, que representa los retardos presentes en la red al establecer una comunicación, es el retardo "extremo a extremo" o latencia.

Los servicios de comunicación en tiempo real son muy sensibles a este efecto, por lo que el retardo máximo en un sentido entre emisor y receptor es de 150 mseg para lograr alta calidad; el retardo entre 150 y 400 mseg es aceptable pero no es un valor ideal y el retardo superior a $400 \mathrm{mseg}$ disminuye la calidad del servicio y puede obstaculizar la interactividad en la comunicación (Rec. UIT-T G.1142003; VoipForo, s.f.).

\section{Variación del retardo}

En esta categoría los parámetros analizan la variabilidad del tiempo de retardo de los paquetes IP dentro de la red de comunicación. El parámetro seleccionado dentro de esta categoría es el jitter o variabilidad del retardo de transmisión.

Los paquetes son enviados en intervalos regulares desde el emisor, por lo que la variación en el tiempo de llegada de los paquetes en el receptor

\section{Delay}

This parameter considers the delay times that the packets suffer between transmitter and received within the network, i.e., the delays that appear when the service is established, from the moment that a single user starts the communication, passing through all the signaling protocols, intermediate memories, packaging and codification processes, and sending of the packets, until the arrival of the information puede ser ocasionada por la congestión de la red, la falta de sincronización o por las diferentes rutas que toman los paquetes para llegar al destino. El jitter debe ser menor a $100 \mathrm{~ms}$ para que pueda ser compensado y no afecte la calidad del servicio (Castillo, Martínez, Díaz, \& Puig, 2016).

\section{Pérdida de información}

Los parámetros dentro de esta categoría están relacionados con la pérdida de información al establecer una co- 
municación en la red. El parámetro seleccionado dentro de esta categoría para conformar el modelo de calidad del servicio de videollamada es el de pérdida de paquetes. Existen varios factores en la red que ocasionan la pérdida de paquetes, como la congestión o saturación en el canal donde se están trasmitiendo los datos, las fallas en el enlace o un ancho de banda insuficiente.

En las aplicaciones en tiempo real es necesario que los paquetes lleguen en el tiempo establecido para que la calidad del servicio no se vea afectada, pero cuando este parámetro se presenta de forma excesiva o consecutiva, no debe superar un porcentaje para que la calidad de voz y video sea aceptable para el usuario. Una pérdida de paquetes del $1 \%$ puede generar congelamiento en el video o pérdida de audio, una pérdida del $2 \%$ puede hacer que degrade la calidad del video aunque el audio pueda ser aceptable, pero una pérdida de paquetes por encima del $2 \%$ es considerado inaceptable (ACT, s.f.).

\section{B. Infraestructura general de la red}

Para aplicar el modelo que permita medir la QoS de una videollamada en una red IMS virtualizada es necesario definir e identificar el hardware y software a utilizar, así como la topología general de la red en donde se ejecutará el servidor y los clientes IMS.

\section{Hardware y software}

El hardware utilizado son los equipos de la plataforma Telco 2.0 del Departamento de Telemática de la Universidad del Cauca (Popayán, Colombia), junto con los equipos personales de los estudiantes. En cuanto al software, se usan programas de acceso libre, de fácil instalación y ejecución. En la TABLA 2 se describe el hardware y el software utilizados para el establecimiento del servicio de videollamada sobre una red IMS.

\section{Topología general de la red}

La plataforma Telco 2.0 de la Universidad del Cauca cuenta con una infraestructura de red en donde será instalado el servidor (Core IMS) que permitirá establecer la comunicación del servicio de videollamada entre los usuarios finales. La topología de red ilustrada en la Figura 1, hace parte de la arquitectura con la que cuenta la plataforma, la cual será utilizada al momento de implementar el servidor IMS y establecer el servicio de videollamada.

El router y el switch son dispositivos que permiten direccionar los datos dentro de la red y el virtual connect habilita puertos de red virtuales, en este caso serán utilizados por el blade, el cual dispone de una distribución de VMWare que le permite desplegar máquinas virtuales con diferentes características, de acuerdo con las necesidades del usuario. Este posee un cliente (VMware vSphere Client) que, de acuerdo con los permisos asignados al usuario, permite administrar o solo utilizar dichas máquinas virtuales. Dentro de estas máquinas virtuales se encuentra instalado el Core IMS, el cual es el servidor del servicio estudiado. into reception and the information interpretation, etc. In this category, the selected parameter, which represents the delays in the network when the establishment of a communication is performed, is the end-to-end delay or latency.

The real-time communication services are very sensible to the previous effect (i.e., the latency); due to this, the maximum delay in one way (between transmitter and receiver) is $150 \mathrm{~ms}$ to achieve a high-quality communication. Values between $150 \mathrm{~ms}$ and $400 \mathrm{~ms}$ are acceptable, but they are not neither ideal nor the wanted ones. On the other hand, values higher than 400 ms reduce the quality of service and can block the interactivity in the communication (ITU-T G.1142003 Rec.; VoipForo, n.d.).

\section{Delay variation (jitter)}

In this category, the parameters assess the variability of the IP packet delay time in a communications network. The selected parameter in this category is the so-called jitter or variability in the transmission delay.

The packets are sent in regular intervals from the transmitter; hence, the variation in the arrival time of the packets in the receiver can be caused by the network congestion, the lack of synchronization, or by the different routes the packets consider when reaching its destination. The jitter should be lower than $100 \mathrm{~ms}$ to be compensated and avoid the affectation in the quality of service (Castillo, Martínez, Díaz, \& Puig, 2016).

\section{Information loss}

The parameters in this category are related with the information loss when a communication process is established in the network. The selected one from this category to define the video-call quality of service model is the packet loss. There are several factors in the network that cause packet loss, some of them are congestion or saturation in the channel where the data is being transmitted, the failures in the link, or an insufficient bandwidth.

In real-time applications, it is essential that the packets arrive in the established time to avoid affectations in the quality of service. When these losses are present in an excessive or consecutive manner, it should not be higher than a certain percentage to ensure that the quality of the voice and video is acceptable for the end user. A 1\% packet loss can entail freezing in the video or loss in the audio; a $2 \%$ value in loss degrades the video quality, although the audio might be acceptable. Nevertheless, a value higher than $2 \%$ is considered as unacceptable (ACT, n.d.). 
Table 2. Hardware and software of the network / Hardware y software de la red

\begin{tabular}{|c|c|c|c|}
\hline \multicolumn{2}{|l|}{ Hardware } & \multicolumn{2}{|l|}{ Software } \\
\hline Elements & Description & Elements & Description \\
\hline HP 5500 switch & $\begin{array}{l}\text { Switch HP series } 5500 \text {, layer } \\
2 \text { y } 3 \text { with } 24 \text { RJ-45 Gigabit } \\
\text { Ethernet ports / Switch HP } \\
\text { serie } 5500 \text {, capa } 2 \text { y } 3 \text { con } 24 \\
\text { puertos Rf-45 Gigabit Ethernet. }\end{array}$ & VMWare ESXi & $\begin{array}{l}\text { Bare-metal type hypervisor (type 1) that } \\
\text { allows to deploy and execute virtual } \\
\text { machines in the same physical space } \\
\text { / Hipervisor tipo Bare-metal (tipo 1) que } \\
\text { permite desplegar y ejecutar varias máquinas } \\
\text { virtuales sobre el mismo equipo físico. }\end{array}$ \\
\hline Virtual Connect & $\begin{array}{l}\text { HP Virtual network connec- } \\
\text { tor of } 4 \text { individual network } \\
\text { interface cards [NIC] / Conec- } \\
\text { tor de red virtual HP de } 4 \text { NIC } \\
\text { individuales con su propio ancho } \\
\text { de banda dedicado. }\end{array}$ & Ubuntu 14.04 LTS & $\begin{array}{l}\text { Linux distro that provides an operating } \\
\text { system focused on personal computers } \\
\text { / Distribución de Linux que brinda un siste- } \\
\text { ma operativo enfocado a equipos de escritorio. }\end{array}$ \\
\hline Blade BL460 Gen 9 & $\begin{array}{l}\text { HPE server with } 2 \text { Intel Xeon } \\
\text { processors, each one with } 12 \\
\text { cores and } 2 \text { TB of memory } \\
\text { with DIMM of } 128 \mathrm{~GB} / \\
\text { Servidor HPE de } 2 \text { procesadores } \\
\text { Intel Xeon con } 12 \text { núcleos en cada } \\
\text { procesador y memoria de } 2 \text { TB } \\
\text { con DIMM de } 128 \text { GB. }\end{array}$ & Open IMS Core & $\begin{array}{l}\text { Open source implementation of IMS } \\
\text { developed by the Fraunhofer Systems } \\
\text { Institute of Open Communication } \\
\text { (FOKUS) in Berlin (Germany) / Imple- } \\
\text { mentación open source de IMS desarrollada } \\
\text { por el Instituto Fraunhofer de Sistemas de } \\
\text { Comunicación Abierta (FOKUS) en Berlin } \\
\text { (Alemania). }\end{array}$ \\
\hline MSA 2040 & $\begin{array}{l}\text { HPE storage matrix with } \\
6 \text { disks of } 600 \mathrm{~GB} \text {, with } \\
\text { maximum capacity of } 768 \\
\text { TB / Matriz de almacenamiento } \\
\text { HPE de } 6 \text { discos de } 600 \text { Gb con } \\
\text { capacidad máxima de } 768 \text { TB. }\end{array}$ & Fokus Monster Client & $\begin{array}{l}\text { Fraunhofer IMS client that provides } \\
\text { a high-level API to access the IMS } \\
\text { services / Cliente IMS de Fraunhofer que } \\
\text { proporciona una API de alto nivel para } \\
\text { acceder a los servicios de IMS. }\end{array}$ \\
\hline Asus-X550L & $\begin{array}{l}\text { Asus laptop with } 8 \mathrm{~GB} \text { of } \\
\text { RAM with Intel Core i5 } \\
\text { processor / Equipo portátil Asus } \\
\text { de } 8 \text { GB de RAM con procesador } \\
\text { Intel Core i5. }\end{array}$ & Wireshark & $\begin{array}{l}\text { An open source network protocol } \\
\text { analyzer available for Windows and } \\
\text { Unix hosts / Analizador de protocolos de } \\
\text { red de código abierto disponible para platafor- } \\
\text { mas Windowes y Unix. }\end{array}$ \\
\hline DELL-Inspiron & $\begin{array}{l}\text { DELL laptop with } 6 \mathrm{~GB} \text { of } \\
\text { RAM and Intel Core i5 pro- } \\
\text { cessor / Equipo portátil DELL } \\
\text { de } 6 G B \text { de RAM con procesador } \\
\text { Intel Core } i 5 \text {. }\end{array}$ & Wondershaper & $\begin{array}{l}\text { Linux traffic controller that allows to } \\
\text { limit the bandwidth for both the uplink } \\
\text { and the downlink in a network interfa- } \\
\text { ce / Controlador de tráfico para Linux, que } \\
\text { permite limitar el ancho de banda, tanto para } \\
\text { el enlace de subida, como para el de bajada de } \\
\text { una interfaz de red. }\end{array}$ \\
\hline
\end{tabular}

\section{B. General infrastructure of the network}

To apply the model that allows the measurement of the QoS in a video-call over an IMS virtualized network, it is necessary to define and identify the hardware and software to be used plus the general topology of the network where the server and IMS clients will run.

\section{Hardware and software}

The employed hardware elements are the equipment of the TELCO2.0 platform of the telematics department of

\section{Caracterización de la red}

Consiste en definir las variaciones que van a aplicarse sobre su dimensionamiento o topología, de manera que, aplicando el modelo de QoS definido, se pueda establecer los efectos sobre la calidad en el servicio de videollamada. La red física de la Figura 1 garantiza una calidad de servicio fija, ya que esta depende, además del tráfico y de la congestión de la red, de las características y especificaciones de los equipos utilizados al implementar el servicio. Por esta razón es necesario establecer una red virtual que 


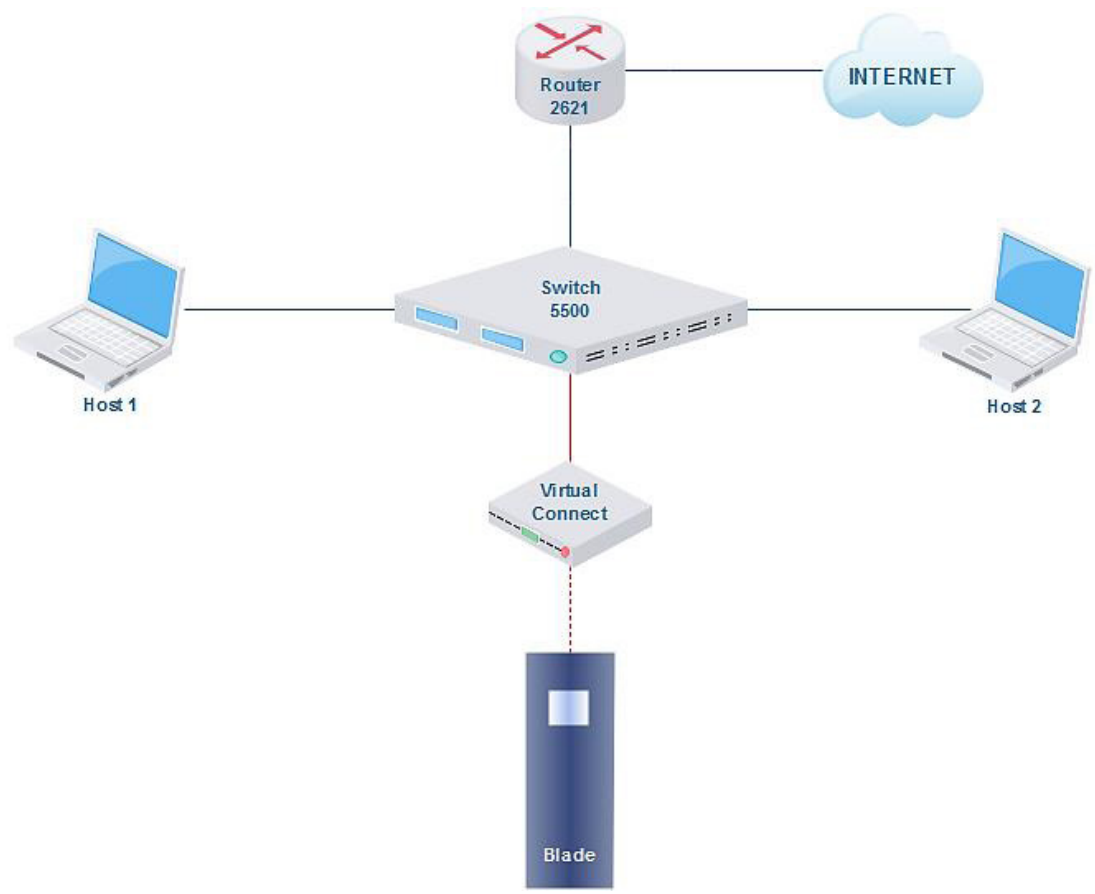

Figure 1. General topology of the network / Topología general de la red the Universidad del Cauca (Popayán, Colombia), along with the personal laptops of the authors. Regarding the software, we employed free access ones, pursuing easy installation and execution processes. TABLE 2 describes the employed hardware and software for the establishment of the video-call service in an IMS network.

\section{Network general topology}

The TELCO2.0 platform of the Universidad del Cauca consists of a network infrastructure where the server (Core IMS) was installed, this allowed to establish a communication via the video-call service between the end users. The network topology (showed in FIgure 1) is part of the platform architecture, which was employed to implement the IMS server and establish the video-call service.

permita modificar las características y las condiciones de la red, con lo cual se evidencien variaciones en cuanto a la calidad del servicio.

Para identificar la QoS del servicio de videollamada sobre la red IMS virtualizada es necesario realizar un análisis de la escalabilidad de la red, un factor que permite identificar el rendimiento y estudiar el comportamiento de la red al aumentar el número de usuarios que utilizan, en este caso, el servicio de videollamada. De esta manera se genera un patrón que permite identificar hasta qué punto se garantiza una QoS de acuerdo con las características

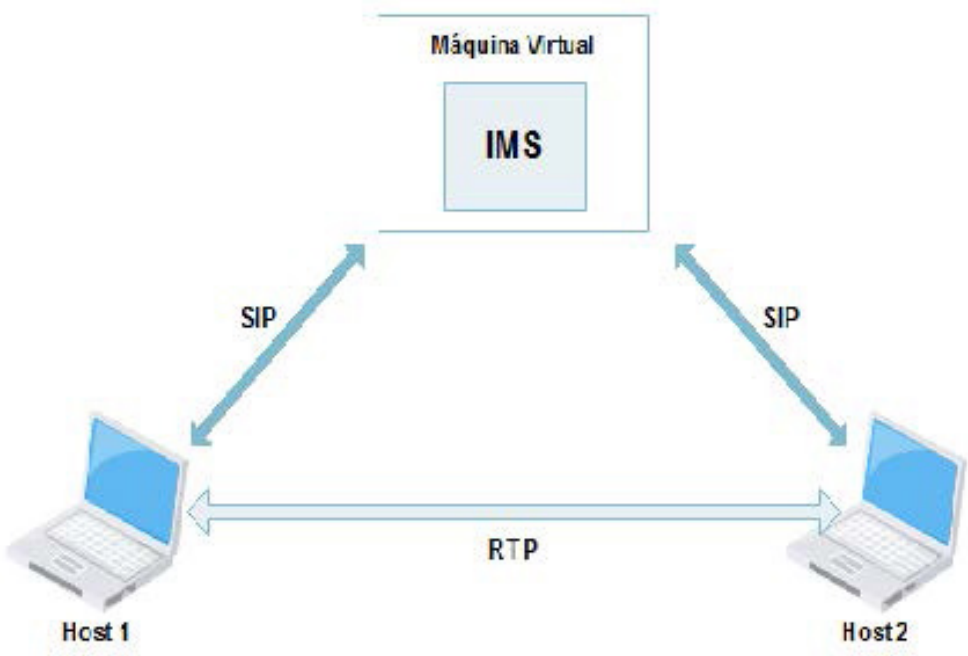

Figure 2. Topology of vertical scalability / Topología escalabilidad vertical
The router and the switch are two devices that allow to redirect the data inside the network, whilst the virtual connect enables virtual network points — which will be used by the Blade - This Blade server has a VMWare distribution that grants to deploy virtual machines with several characteristics according to the user needs. It also has a client (VMWave vSphere Client) that, in accordance with the assigned permissions to the users, allows either manage or only use the virtual machines. Within these virtual machines, the Core IMS is installed, which is our server containing the studied service.

\section{Characterization of the network}

It consists in the definition of the variations to be applied in the network sizing or topology; consequently, when the application of the defined QoS model is performed, the establishment of the quality effects in the video-call service can be set up. The physical network in Figure 1 guarantees a fixed QoS. This latter, since the QoS depends - besides the traffic and the network congestion - on the features and specifications of the equipment used to implement the service. For this reason, it is necessary to establish a virtual network that allows the modifying of the network features and conditions. This will allow to evidence changes regarding the quality of service. 
With the purpose to identify the video-call service QoS in the IMS virtualized network, it is necessary to perform a scalability analysis in the network. This is a parameter that permits to identify the performance and study the network behavior when the users consuming the video-call service grow. For this reason, a pattern that grants the identification of the point where the QoS is guaranteed according to the virtual network features is generated. Two types of scalability are well distinguished: vertical and horizontal. These two types were analyzed by defining the topology and the features of the employed network.

\section{Vertical scalability}

By definition, it is the action of adding more resources to a particular node; i.e., increase the processing memory and number of processor cores, increasing the information processing capacity. In this case, we tried to increase the capacity of the virtual machine where the server was allocated (Core IMS). This allowed us to analyze the effects in the quality of service features to discover the general saturation point of the system. FIGURE 2 presents the employed scenario when the vertical scalability was used.

\section{Horizontal scalability}

It consists in distributing the load in more than one server. For that, it is necessary to employ a load balancer that splits the traffic between the servers. In this case, we tried to increase the number of IMS servers in order to increase the users assistance capacity in the network. This was done pursuing the QoS features analysis and to find the saturation point where the service capacity is constant. FIGURE 3 presents the employed scenario when the horizontal scalability was employed.

\section{Characterization of the video-call service}

It is very important to define the properties the video-call service has, since it entails a typical telecommunications service (the voice transmission) with a multimedia web service (i.e., video). The video-call service is defined by the ITU in the T-720-1992 recommendation as a "conversational and audiovisual service that grants the bidirectional, symmetric, and real-time transmission of sound and video with movement between two places (from person to person) through networks".

The audio has a significantly lower bandwidth demand relative to the video; therefore, its properties must be considered when the implementation of a multimedia service is performed. In our case, the audio codec employed by the IMS client for the de la red virtual. Se distinguen dos tipos de escalabilidad: vertical y horizontal, las cuales se analizaron, definiendo la topología y las características de la red utilizada.

\section{Escalabilidad vertical}

Consiste en añadirle más recursos a un nodo en particular, es decir, en aumentar la memoria de procesamiento y el número de núcleos del procesador, aumentando así la capacidad de procesamiento de información. En este caso se busca aumentar la capacidad de la máquina virtual en donde estará el servidor (Core IMS) y, de esta manera, analizar los efectos sobre las características de calidad del servicio para encontrar el punto de saturación del sistema en general. En la Figura 2 se observa el escenario utilizado al aplicar la escalabilidad vertical.

\section{Escalabilidad horizontal}

Consiste en distribuir la carga en más de un servidor, para ello es necesario utilizar un balanceador de carga que divida el tráfico entre los servidores. En este caso, se busca incrementar el número de servidores IMS, con el fin de aumentar la capacidad de atención de usuarios en la red para analizar las características de calidad del servicio y encontrar el punto de saturación en el que la capacidad del servicio se mantiene constante. En la Figura 3 se observa el escenario utilizado al aplicar la escalabilidad horizontal.

\section{Caracterización del servicio de videollamada}

Es indispensable definir las propiedades que tiene el servicio de videollamada, ya que este integra un servicio de telecomunicaciones típico, como es la transmisión de voz, con un servicio multimedia web (video). El servicio de videollamada, según la Recomendación UIT-T 720-1992, se define como un "servicio audiovisual conversacional que permite la transferencia bidireccional, simétrica y en tiempo real, de sonido y video con movimiento entre dos lugares (de persona a persona) a través de redes".

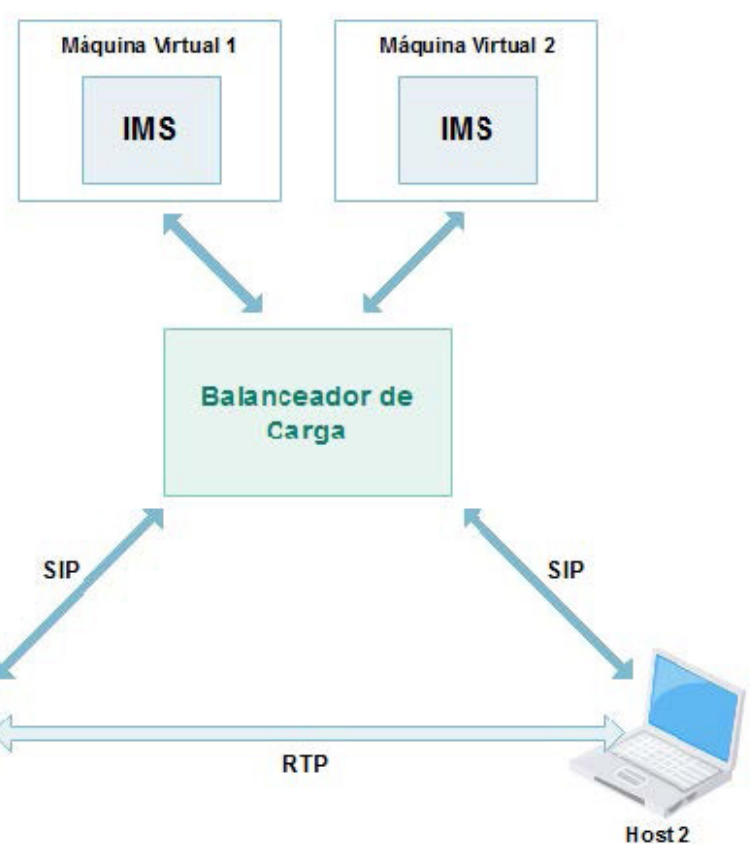

Figure 3. Topology of horizontal scalability / Topología escalabilidad horizontal 
Table 3. Physical features of the virtual machines / Características físicas de las MV

\begin{tabular}{lrr}
\hline Machine name & RAM & Processors (\#) \\
\hline CoreIMS1 & $512 \mathrm{MB}$ & 1 \\
CoreIMS2 & $1 \mathrm{~GB}$ & 1 \\
CoreIMS3 & $1 \mathrm{~GB}$ & 2 \\
CoreIMS4 & $2 \mathrm{~GB}$ & 2 \\
\hline
\end{tabular}

El audio tiene una demanda de ancho de banda significativamente más baja que la del video, por lo que sus propiedades deben ser consideradas al implementar un servicio multimedia. En este caso, el códec de audio utilizado por el cliente IMS para el establecimiento de la videollamada es el G.711 (Rec. UIT-T G.711), el cual proporciona un flujo de datos de 56 o $64 \mathrm{Kbit} / \mathrm{s}$ y representa la voz humana mediante palabras de 8 bits, con una tasa de 8000 muestras por segundo.

El vídeo en una aplicación de videollamada se puede comprimir en tiempo real para proporcionar la mejor calidad de vídeo, según el ancho de banda disponible de extremo a extremo entre usuarios, dependiendo del códec utilizado. El códec de video utilizado por el cliente IMS es el H.263 (Rec. UIT-T H.263), el cual soporta un conjunto limitado de tamaños de imagen y especifica un algoritmo de codificación y decodificación de señales de video en tiempo real. El propio estándar no especifica una tasa de bits concreta, pero utiliza velocidades bajas para la transmisión.

\section{Plan de pruebas y resultados}

El plan de pruebas abarca escenarios favorables y desfavorables para la videollamada, obteniendo valores o rangos de valores que permiten determinar la calidad de la comunicación según los parámetros escogidos para el modelo. Estos resultados pueden ser usados como condiciones iniciales en posteriores investigaciones, reduciendo considerablemente el número de pruebas que deben ser ejecutadas.

Se analiza la escalabilidad vertical y horizontal de la red con el fin de determinar qué tipo de escalabilidad ofrece las mejores condiciones de trabajo para Open IMS Core. Además, se estudian los parámetros de calidad como retardo, pérdida de paquetes y jitter, al variar el ancho de banda utilizado por los usuarios, ya que es importante escoger el valor adecuado para que una videollamada funcione correctamente y así no desperdiciar recursos de la red.

\section{A. Escalamiento vertical}

Se establecen cuatro casos de estudio en donde solo se varían las características físicas que el hipervisor permite modificar, como la memoria RAM y el número de procesadores asignados. En la documentación que se encuentra en la plataforma de Open Core IMS (s.f.), no se especifican valores exactos, solo se pide disponer de varios gigabytes video-call establishment is the G.711 one (ITU-T G.711 recommendation). This codec provides a data flow of 56/64 kbps and it represents the human voice with an 8-bit word with a sampling rate of 8,000 samples per second.

The video in a video-call application can be compressed in real-time to provide a better video quality given the available bandwidth between the end users and also depending on the used codec. The codec used for the IMS client is the H.263 one (ITU-T H.263 recommendation), which supports a limited image size and specifies a coding/decoding algorithm of video signals in real-time. The standard by itself does not provide a concrete bit rate, but relatively low speeds are employed for the transmission.

\section{Test plan and results}

The test plan entails favorable and unfavorable scenarios for the video-call, obtaining values - or a range of valuesthat allow the determination of the quality in the communication as per the chosen parameters by the model. These results can be used as initial conditions for further research, reducing considerably the number of tests to be executed.

We analyzed the network vertical and horizontal scalability to determine which of them offers the most favorable working conditions for the Open IMS Core. Besides, we studied the quality parameters such as delay, packet loss, and jitter by varying the bandwidth employed for the users. This, since it is important to choose the adequate value to allow a correct operation of a video-call and avoid the waste of the network resources.

\section{E. Vertical scaling}

We established four study cases, where only the features the hypervisor allows to modify, i.e., the RAM memory and the number of assigned processors are modified. In the documentation of the Open Core IMS available online, no exact values are specified; only the advice to provide several GB of RAM and several CPU cores (Open Core IMS, n.d.). For this reason, we took some values that allowed the analysis of the virtual machines in the worst and best cases, as TABLE 3 presents.

For the scope of this project, we monitored the response time of the IMS Core to the incoming requests and the lost packets unattended in a certain time lapse due to the core saturation. These results presented a considerable similarity on each study case, generating a controversy when a conclusion regarding the improvements of the cores arises. This, since we expected that, with an increase in the physical resources 


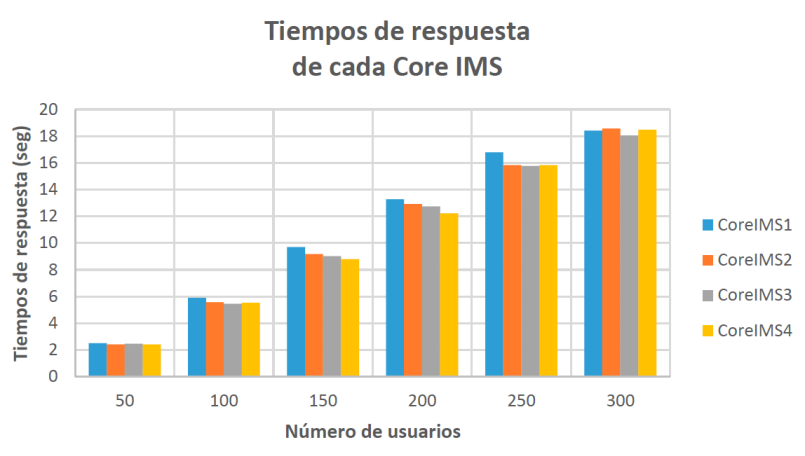

Figure 4. Response time for each IMS Core / Tiempos de respuesta de cada Core IMS

of the virtual machines, better results would be achieved related to the response time, but these times did not present any improvements when the resources are increased. Figure 4 presents a comparison between the response times obtained using each IMS Core with a variation in the number of users in the network. Here, the graph tends to keep stable for a fixed number of users. This is clear when the machine resources are increased.

Regarding the packet loss, we considered the SIP messages not attended by the core, where the results show that the trend in the loss is similar on each study case. If there is a large number of users, the higher the lost packets on each connection will be, as Figure $\mathbf{5}$ shows.

Through these results, we can infer that the vertical scalability does not generate substantial changes in the system behavior when it is applied in the Open IMS Core in a virtualized network. This, since no improvements were observed when the physical resources of the virtual machines were increased.

\section{F. Horizontal scaling}

We assessed the horizontal scalability of the IMS Core to analyze the network capacity to distribute the connection requests between several servers through a load balancer. For this reason, we added two study cases where two and three IMS Cores were associated to the load balancer. The selected virtual machines correspond to the employed ones in the study case 1, i.e., a machine with $512 \mathrm{MB}$ of RAM and a single CPU core.

Figure 6 presents how, when the requests traffic is split between several cores, the response time decreases considerably when the number of users grows. This improves the network efficiency, since all the associated cores work as a single one, increasing the number of users attended.

To analyze this progress, we present a graph of the memory percentage versus the number of IMS Cores (FIGURE de RAM y de varios CPU/core. En este caso se toman unos rangos de valores que permiten analizar el funcionamiento de las máquinas virtuales en el peor y en el mejor de los casos, como se observa en la TABLA 3.

Para los efectos, se monitorea el tiempo de respuesta del Core IMS a las peticiones entrantes y los paquetes perdidos que no son atendidos en un lapso de tiempo, debido a la saturación del core. Estos resultados presentaron una gran similitud en cada caso de estudio, lo que genera una controversia a la hora de establecer una conclusión frente a las mejoras del core, ya que se esperaba que, al aumentar los recursos físicos de las máquinas virtuales, se obtuvieran mejores resultados en cuanto al tiempo de respuesta, pero estos tiempos no mejoran a medida que se aumentan dichos recursos físicos. En la Figura 4 se comparan los tiempo obtenidos en cada Core IMS al variar el número de usuarios en la red, donde se observa la tendencia del tiempo de respuesta a mantenerse estable para un número fijo de usuarios a medida que incrementan los recursos de la máquina.

En cuanto a la pérdida de paquetes, se consideran los mensajes SIP que no fueron atendidos por el core, donde los resultados muestran que la tendencia de pérdida es similar en cada caso de estudio. A mayor número de usuarios mayor será el número de paquetes perdidos en cada conexión, como se observa en la Figura 5.

A partir de estos resultados se puede indicar que la escalabilidad vertical no genera cambios sustanciales en el comportamiento del sistema al aplicarla sobre el Open IMS Core en una red virtualizada, ya que no se observan mejoras al aumentar los recursos físicos de las máquinas virtuales.

\section{B. Escalamiento horizontal}

Se estudia la escalabilidad horizontal del Core IMS con el fin de analizar la capacidad de la red al distribuir las peticiones de conexión entre diferentes servidores, por medio de un balanceador de carga. Para ello se adicionan dos casos de estudio, en los cuales se asocian dos y tres Core IMS al balanceador de carga. En este caso, las máquinas virtuales seleccionadas corresponden a la utilizada en el caso de estudio 1, la cual cuenta con 512 MB de RAM y un núcleo de procesador. En la Figura 6 se observa cómo, al dividir el tráfico de peticiones entre varios core, el tiempo de respuesta

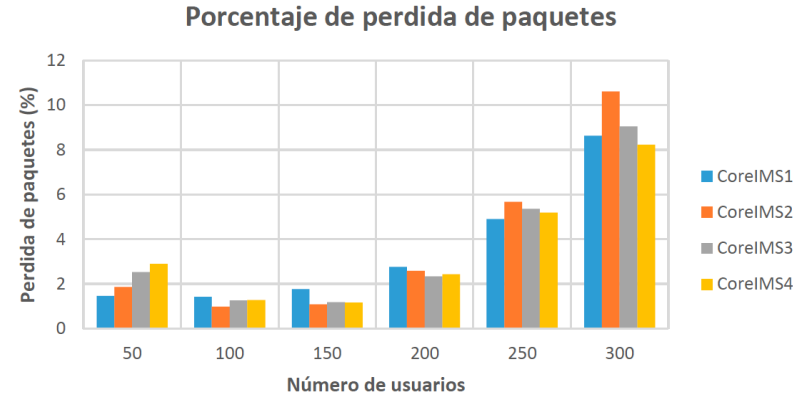

Figure 5. Packet loss on each IMS Core / Pérdida de paquetes de cada Core IMS 


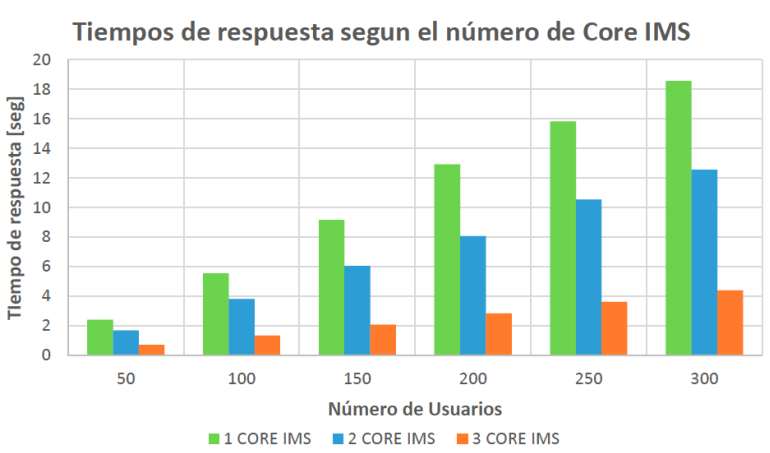

Figure 6. Response times as per the number of IMS Cores / Tiempos de respuesta según el número de Core IMS

disminuye considerablemente a medida que aumenta el número de usuarios. Esto mejora la eficiencia de la red, ya que todos los core asociados trabajan como uno solo, incrementando el número de usuarios atendidos.

Para analizar dicho progreso se grafica el porcentaje de mejora según el número de Core IMS (Figura 7), en donde este porcentaje representa el promedio de los tiempos de respuesta de los usuarios atendidos por dos y tres core con respecto a los clientes atendidos por un core. Aquí se observa la mejora al aumentar el número de core, ya que para dos la mejora es del $33 \%$, y para tres, del $76 \%$, lo que indica que al aumentar el número de Core IMS, el tiempo de respuesta disminuye, incrementando así el número de usuarios registrados en el Core IMS. Este porcentaje de mejora permanece estable al aumentar el número de usuarios ya que el incremento en los tiempos de respuesta por usuario es aproximadamente constante, como se puede apreciar en la Figura 7.

\section{Parámetros de calidad}

La metodología de pruebas consiste en establecer una videollamada entre dos clientes IMS limitando el ancho de banda de los equipos en donde están ubicados los usuarios. Inicialmente los usuarios se registran en el core por medio de mensajes SIP, el core valida la información de los usuarios y permite el establecimiento de la videollamada intercambiando paquetes RTP. Para estudiar los parámetros de calidad, se examinan únicamente los paquetes involucrados durante la videolla-

\section{Retardo de Transmisión}

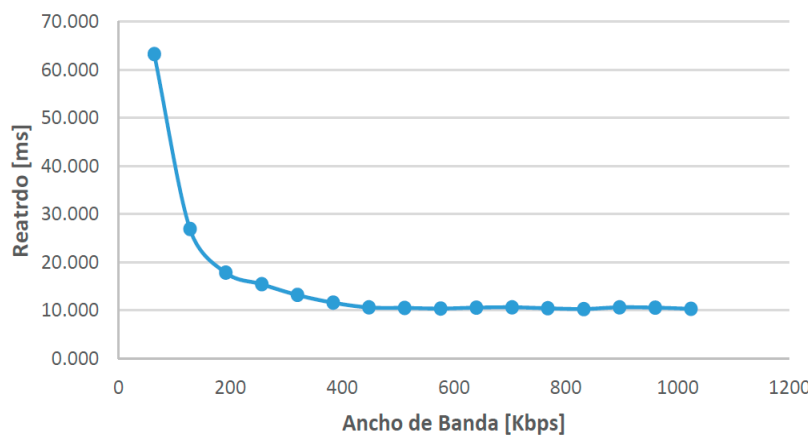

Figure 8. Transmission delay / Retardo de transmisión
Porcentaje de mejora según el número de Core IMS

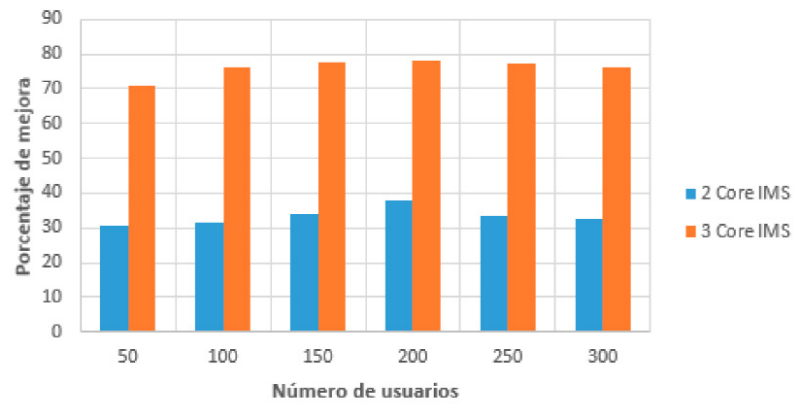

Figure 7. Improvement percentage as per the number of IMS Cores / Porcentaje de mejoras según el número de Core IMS

7). This percentage represents the average of the response times for the attended users by two and three cores regarding the clients attended by a single core. The reader should be able to see the improvements when an increase in the number of cores is executed as follow: 33\% for two cores and $76 \%$ for three cores relative to the performance with a single core. These results entail the fact that, when an increase in the number of IMS cores is executed, the response time decreases and the number of users registered in the IMS Core is enhanced (i.e., ability to attend more users). These percentages are stable when the number of users grows, since the increase in the response times per user is approximately constant, as the reader might see in Figure 7.

\section{G. Quality parameters}

The testing methodology consists of establishing a video-call between two IMS clients by limiting the bandwidth of the user computers. Initially, the users are registered in the core via SIP messages and the core validates the user information and allows the establishment of the video-call by exchanging RTP packets.

With the intention of studying the quality parameters, we examined only the packets involved during the videocall, i.e., the RTP packets transferred during the video-call. This analysis was performed via the protocol analyzer called Wireshark, which allows to determine the values of packet loss, delay, and jitter. Likewise, we studied how these parameters are affected by the bandwidth limitation in the video-call.

\section{Delay}

The executed tests were under optimal network conditions (laboratory tests); consequently, there are no nodes that add neither queuing nor processing delays. Also, there are not large connections adding significative transmission delays. For that reason, we considered the transmission delay in these tests. 


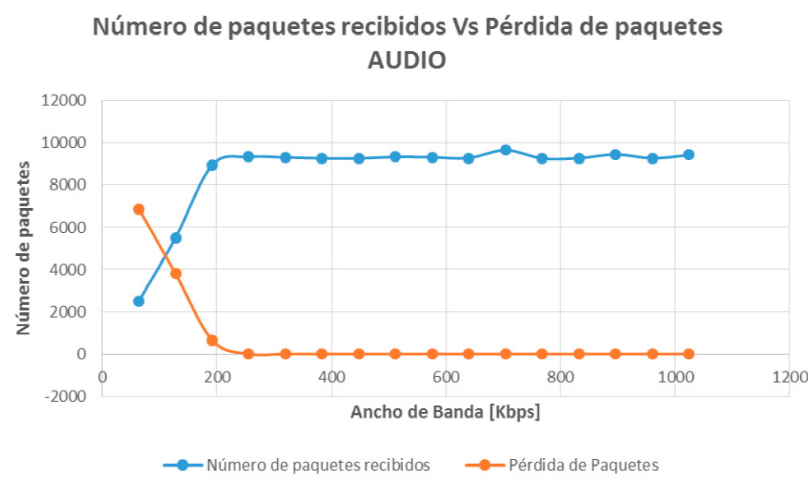

Figure 9. Audio packets loss / Pérdida de paquetes de audio

In Figure 8, it is possible to see that the obtained behavior is in accordance with the expected one, since when the bandwidth grows, the delays are reduced. The delay stabilizes itself with a value near $10 \mathrm{~ms}$ for a bandwidth of $384 \mathrm{kbps}$. This latter means that, regardless that the bandwidth increases, there will be no more improvements in the transmission delay. Further, the maximum delay is not greater than $150 \mathrm{~ms}$.

\section{Packet loss}

From the obtained results, we can differentiate two analyses: for audio packets and for video packets. This division was performed because the video packets present more loss due to the larger bandwidth demand, affecting the video quality.

In Figures 9 and 10, the lost and received packets with several bandwidth configurations are displayed. It is important to focus that in the audio packets, when the packet loss is stabilized, the number of received packets converges to a single value; nevertheless, the video packets need more bandwidth when the loss is stabilized to maintain the QoS. Punctually, for the analyzed scenario, the audio packet loss become stable from a bandwidth of $256 \mathrm{kbps}$; the video packet loss does the same from $384 \mathrm{kbps}$ of bandwidth.

\section{Jitter}

We analyzed the maximum and average jitter values for both the audio and video packets. The behavior of the jitter

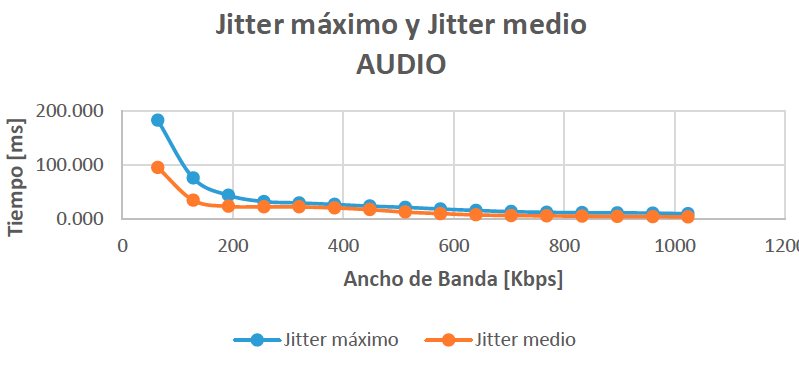

Figure 11. Audio jitter / Jitter de audio

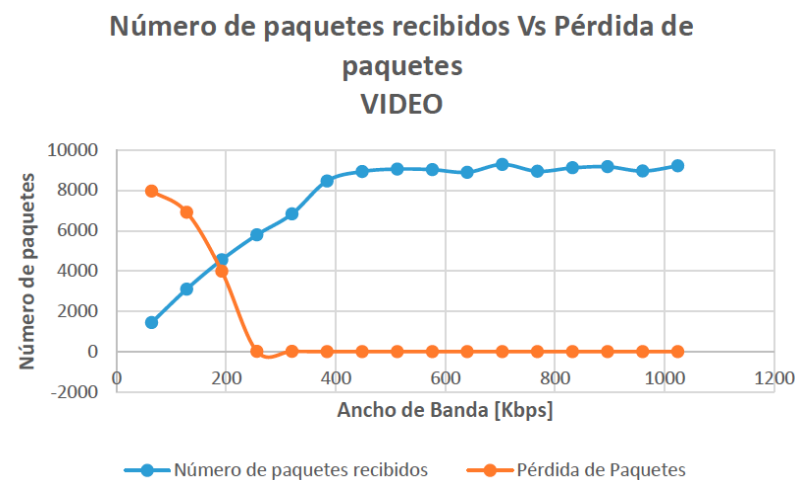

Figure 10. Video packet loss / Pérdida de paquetes video

mada, en este caso se analizan los paquetes RTP desde que inicia hasta que termina la comunicación por medio de Wireshark, el cual permite determinar los valores de pérdida de paquetes, retardo y jitter. Del mismo modo, se estudia cómo se ven afectados dichos parámetros por la limitación de ancho de banda en la videollamada.

\section{Retardo}

Las pruebas realizadas están bajo condiciones de red óptimas (pruebas de laboratorio), por ende, no hay nodos que puedan sumar retardos de cola y de procesamiento ni tampoco enlaces largos que puedan sumar retardos de trasmisión significativos. Por lo tanto, se toma el retardo de transmisión en estas pruebas.

En la Figura 8 se observa que el comportamiento obtenido corresponde al esperado pues, a medida que aumenta el ancho de banda, los retardos disminuyen. El retardo se estabiliza con un valor cercano a los $10 \mathrm{~ms}$ a partir de un ancho de banda de $384 \mathrm{Kbps}$, lo que indica que, por más que se aumente el ancho de banda, a partir de este valor no se van a tener mejoras en los retardos de transmisión. No obstante el máximo retardo no supera el límite de los $150 \mathrm{~ms}$.

\section{Pérdida de paquetes}

En los resultados obtenidos se tienen dos tipos de análisis, uno para paquetes de audio, otro para paquetes de video. Se dividen de esta forma ya que los paquetes de video presentan más pérdidas por efecto de la gran demanda de ancho

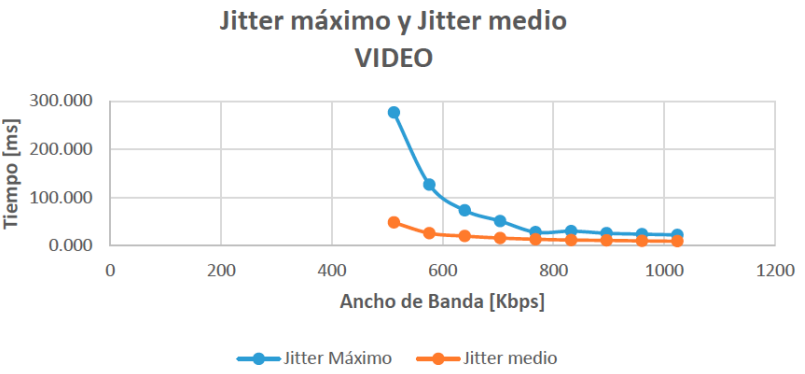

Figure 12. Video jitter / Jitter de video 
Table 4. Bandwidth values as per the quality parameters / Anchos de banda según los parámetros de calidad

\begin{tabular}{lll}
\hline Parámetros de Calidad & Audio (Kbps) & Video (Kbps) \\
\hline Retardo & 64 & \\
Perdida de Paquetes & 256 & 384 \\
"Jitter" & 128 & 640 \\
\hline
\end{tabular}

de banda, afectando así la calidad del video.

En las Figuras $\mathbf{9}$ y $\mathbf{1 0}$ se analizan los paquetes recibidos y los perdidos al aumentar el ancho de banda. Cabe anotar que en los paquetes de audio, al estabilizarse la pérdida de paquetes, también se mantiene el número de paquetes recibidos; pero los paquetes de video necesitan mayor ancho de banda, ya que al estabilizarse la pérdida, estos requieren de un mayor ancho de banda para transmitir más paquetes y mantener la QoS. En este caso, las pérdidas de paquetes de audio son estables a partir de un valor de ancho de banda de $256 \mathrm{Kbps}$ y las de video a partir de $384 \mathrm{Kbps}$.

\section{Jitter}

Se analiza el jitter máximo y medio para los paquetes de audio y video. El comportamiento del jitter de video, respecto del ancho de banda, es similar al jitter de audio, pero estos valores son más elevados, ya que hay mayor cantidad de paquetes de video que demandan más ancho de banda.

Según la teoría (Castillo, Martínez, Díaz, \& Puig, 2016), los valores de jitter deben ser menores a $100 \mathrm{~ms}$ para que la calidad de la videollamada sea óptima, en este caso los valores promedios de jitter de audio son tolerables a partir de $128 \mathrm{Kbps}$, como se ilustra en la Figura 11. Los valores aceptables de video se obtienen a partir de un ancho de banda de $640 \mathrm{Kbps}$ (Figura 12). Para evidenciar este comportamiento, se grafican los datos a partir de un ancho de banda de $512 \mathrm{Kbps}$, como se observa en la Figura 13.

La TABla 4 resume los resultados del ancho de banda requerido para cada uno de los parámetros monitoreados para el servicio de videollamada.

En la Figura 13 se ilustra el comportamiento del video para anchos de banda de 64, 256, 512 y $640 \mathrm{Kbps}$.

De acuerdo con los datos obtenidos en cada prueba, para tener una buena calidad de audio, el ancho de banda debe ser mayor a $256 \mathrm{Kbps}$, para video, el ancho de banda necesario debe ser mayor a $640 \mathrm{Kbps}$. Por ello, el ancho de banda que cumple con las condiciones de los parámetros de calidad para brindar una buena QoS de videollamada es de $640 \mathrm{Kbps}$.

\section{Conclusiones}

El modelo propuesto permitió evaluar la calidad del servicio de videollamada sobre una red IMS virtualizada, al determinar qué tipo de escalabilidad es la apropiada para verificar la eficiencia y el rendimiento de Open IMS Core y qué parámetros de calidad son los adecuados para el análisis de dicho servicio. Según estos datos, la variable

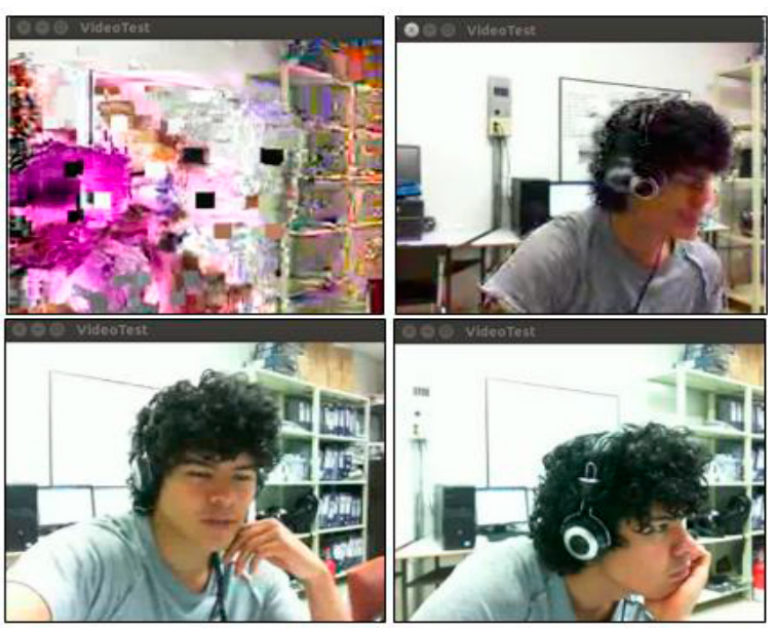

Figura 13. Video quality with bandwidth values of $64,256,512$, and $640 \mathrm{kbps} /$ Calidad de video con anchos de banda de 64 256,512 y $640 \mathrm{Kbps}$

in the video packets is similar to the jitter in the audio ones regarding the bandwidth. However, the values in the first jitter are higher due to the larger number of packets demanding more bandwidth.

As per the theory described by (Castillo, Martínez, Díaz, \& Puig, 2016), the jitter values must be lower than $100 \mathrm{~ms}$ in order to ensure an optimum video quality. For our study case, the average audio jitter is bearable from $128 \mathrm{kbps}$, as FigurE 11 shows. The acceptable video jitter is from $640 \mathrm{kbps}$ of bandwidth (see FIGURE 12). With the aim of evidencing this behavior, we plotted the data from a bandwidth of $512 \mathrm{kbps}$, as per Figure 13 presents.

TABLE 4 summarizes the results of the required bandwidth for each one of the monitored parameters for the video-call service.

In FiguRE 13, we present the behavior of the video for bandwidth values of $64,256,512$, and $640 \mathrm{kbps}$.

According to the data obtained on each test, in order to ensure a good audio quality, the bandwidth must be higher than $256 \mathrm{kbps}$, whilst for the video, the employed bandwidth must be larger than $640 \mathrm{kbps}$. Consequently, the bandwidth that complies with the conditions of the quality parameters to ensure a good QoS for a video-call service is $640 \mathrm{kbps}$.

\section{Conclusions}

The proposed model allowed us to assess the quality of service of a video-call in a virtualized IMS network by determining the type of scalability is the appropriate one to verify the efficiency and the performance of the Open IMS Core system. Further, it allowed us to confirm what quality para- 
meters are the adequate ones for the analysis of that service. As per the data we obtained, the variable that most affects the performance of the Open IMS Core is the number of users, since when an increase of that variable happens, the response time and the information loss also tend to grow.

The network scalability analysis allowed us to identify that the horizontal scaling is a useful strategy to maintain the QoS, since when the incoming requests to the application are split between several IMS Cores, the response times and the packet loss can be controlled in low levels. The vertical scaling does not have a significant impact in the network behavior. The quality parameters selection was adequate, since it allowed to determine the values guaranteeing a good quality of service in the IMS network. For our particular case, these values are reflected in the bandwidth that provides acceptable jitter, packet loss, and delay values ensuring the quality of service of a video-call

\section{Acknowledgement}

The authors express their gratitude to the Universidad del Cauca, specially to the Telematics Department of the Electronic and Telecommunications Engineering faculty for providing the means to carry on the research project described in this document. STT que más afecta el rendimiento de Open IMS Core es el número de usuarios, ya que a medida que esta variable aumenta, se afecta el tiempo de respuesta y la pérdida de información.

El análisis de escalabilidad de la red permitió identificar que el escalamiento horizontal es una estrategia útil para mantener la calidad del servicio, ya que al dividir las peticiones entrantes a la aplicación en diferentes Core IMS se puede mantener los tiempos de respuesta y las pérdidas de paquetes. El escalamiento vertical no tiene impacto sobre el comportamiento del sistema. La selección de los parámetros de calidad fue adecuada ya que permitió determinar los valores que brindan una buena calidad de servicio en la red IMS. En este caso, el valor de ancho de banda que provee valores aceptables de jitter, pérdida de paquetes y retardo, asegurando la calidad del servicio de videollamada.

\section{Agradecimientos}

Los autores expresan su agradecimiento a la Universidad del Cauca, y en especial al Departamento de Telemática de la Facultad de Ingeniería Electrónica y Telecomunicaciones por haber provisto los medios que permitieron llevar a cabo el desarrollo del proyecto de investigación base de la presente publicación. ST 


\section{References / Referencias}

ACT, G. (s.f.). Consideraciones para implementación de videoconferencia via IP. Retrieved from: http://www.grupoact.com.mx/ archivos/Consideraciones\%20para\%20Videconferencia\%20IP.pdf

Blandón, D., Díaz, Y., Guerrero, F. G., Cuellar, J. C., Navarro C, A., \& Ochoa A, C. (2010). Medición de la calidad del servicio en Redes de Próxima Generación en Colombia: Procedimientos de medida de calidad de servicio en redes de próxima generación. Bogotá, Colombia: CINTEL.

Castillo, S., Martínez, R., Díaz, E., \& Puig, P. M. (2016). Quality of experience in the transmission of video over IP. In 7mo Congreso Internacional de Tecnologías y Contenidos Multimedia. Retrieved from: http://www.informaticahabana.cu/sites/ default/files/ponencias/MUL08.pdf

Comisión de Regulación de Telecomunicaciones [CRT]. (2007). Estudio integral de redes de nueva generación y convergencia. Bogotá, Colombia: CRT.

Kurose, J. \& Ross, K. (2013). Computer networking: A top-down approach. Boston, MA: Pearson.

Lara-Paz, M. C. \& Coral-Sarria, H. A. (2017). QoS del servicio de video Ilamada en una red IMS virtualizada [tesis]. Universidad del Cauca: Popayán, Colombia.

Nemati, H., Singhvi, A., Kara, N., \& El Barachi, M. (2014). Adaptive SLA-based elasticity management algorithms for a virtualized IP multimedia subsystem. In Globecom Workshops (GC Wkshps), 2014. IEEE. doi: 10.1109/GLOCOMW.2014.7063377

Open IMS Core. (s.f.). Retrieved from: http://www.openimscore.org/

Recomendación UIT-T F.720-1992. Servicios de videotelefonia - generalidades. Ginebra, Suiza: Union Internacional de Telecomunicaciones.

Recomendación UIT-T G.114-2003, Conexiones y circuitos telefónicos internacionales - Recomendaciones generales sobre la calidad de transmisión para una conexión telefónica internacional completa. Tiempo de transmisión en un sentido. Ginebra, Suiza: Union Internacional de Telecomunicaciones.

Recomendación UIT-T G.711-1990. Modulación por impulsos codificados (MIC) de frecuencias vocales. Ginebra, Suiza: Union Internacional de Telecomunicaciones.

Recomendación UIT-T H.263-2005. Codificación de vídeo para comunicación a baja velocidad binaria. Ginebra, Suiza: Union Internacional de Telecomunicaciones.

VoipForo. (s.f.). QoS Quality of Sevice VoIP. (VoIPForo). Retrieved from: http://www.voipforo.com/QoS/QoS_Jitter.php. 


\section{CURRICULUM VITAE}

Maria Camila Lara Paz. Student of Electronics and Telecommunications Engineering with emphasis in telecommunications in the Universidad del Cauca (Popayan, Colombia). Candidate for the title of Electronics and Telecommunications Engineer. Her interest areas are the internet of things, big data, network configurations, and project management / Estudiante de Ingeniería en Electrónica y Telecomunicaciones (énfasis en Ingeniería Telecomunicaciones) de la Universidad del Cauca (Popayán, Colombia), aspirante al título de Ingeniero en Electrónica y Telecomunicaciones. Sus áreas de intereses en la investigación incluyen: Internet de las Cosas [loT], big data, configuración de redes y gestión de proyectos.

Heyman Andrés Coral Sarria. Student of Electronics and Telecommunications Engineering with emphasis in telematics in the Universidad del Cauca (Popayan, Colombia). Candidate for the title of Electronics and Telecommunications Engineer. Mobile and web applications developer, his areas of interest are internet of things, databases handling and management, big data, and cloud computing / Estudiante de Ingeniería en Electrónica y Telecomunicaciones (énfasis en Ingeniería Telemática) de la Universidad del Cauca (Popayán, Colombia), aspirante al título de Ingeniero en Electrónica y Telecomunicaciones. Desarrollador de aplicaciones móviles y web, manipulación de base de datos y administración de servidores. Sus áreas de intereses en investigación incluyen: Internet de las Cosas [loT], big data y cloud computing.

Eduardo Rojas Pineda. Electronic Engineer of the Universidad del Cauca (Popayan, Colombia), M.Sc. in Systems and Communication Networks from the Universidad Politécnica de Madrid (Spain) and M.Sc. in University Management from the Universidad de los Andes (Bogota, Colombia). He is a full-time professor of the telematics department in the Electronic and Telecommunications Engineering faculty in the Universidad del Cauca / Ingeniero Electrónico de la Universidad del Cauca (Popayán, Colombia), con Máster en Sistemas y Redes de Comunicaciones de la Universidad Politécnica de Madrid (España) y Máster en Dirección Universitaria de la Universidad de los Andes (Bogotá, Colombia). Es profesor de tiempo completo del Departamento de Telemática de la Facultad de Ingeniería Electrónica y Telecomunicaciones de la Universidad del Cauca. 